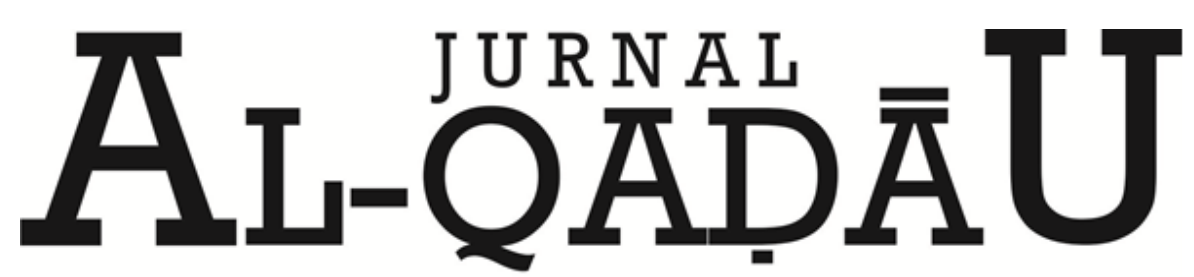

PERADILAN dan HUKUM KELUARGA ISLAM

\title{
Kedudukan Lembaga Fatwa dalam Fikih Kontemporer
}

The Essence of Fatwa Institution in Fikih Contemporary

Supardin

Dosen Fakultas Syariah dan Hukum UIN Alauddin Makassar

Email: supardinpati@gmail.com

\begin{tabular}{|c|c|}
\hline $\begin{array}{c}\text { Info } \\
\text { Artikel } \\
\end{array}$ & Abstract \\
\hline $\begin{array}{l}\text { Diterima } \\
21 \\
\text { September } \\
2018\end{array}$ & $\begin{array}{l}\text { Fatwa yang dikeluarkan oleh MUI sebagai suatu keputusan tentang } \\
\text { masalah ijtihadiyah yang terjadi di Indonesia. Fatwa itu dijadikan } \\
\text { sebagai pegangan atau dasar hukum terhadap pelaksanaan ibadah umat } \\
\text { Islam di Indonesia. Persoalan-persoalan hukum Islam itu bukan hanya } \\
\text { masalah ibadah, tetapi juga menyangkut persoalan lain seperti } \\
\text { mu'amalah. Suatu kenyataan yang tidak dapat dipungkiri lagi, bahwa } \\
\text { banyak kasus yang dihadapi oleh umat Islam yang memerlukan jawaban } \\
\text { dari lembaga yang berwewenang. Adanya lembaga resmi seperti MU, } \\
\text { umat Islam tidak kehilangan arah untuk meminta fatwa menyangkut } \\
\text { hukum Islam kontemporer. }\end{array}$ \\
\hline
\end{tabular}

22

Oktober

2018

\section{Revisi II}

12

Nopember

2018

\section{Disetujui}

04

Desember

2018

\section{Kata Kunci : Fatwa, Kontemporer}

The fatwa issued by the MUI as a decision on the issue of ijtihadiyah occurred in Indonesia. The fatwa is used as a basis or legal basis for the implementation of Muslim worship in Indonesia. The issues of Islamic law are not only a matter of worship but also involve other issues such as trade relations. An undeniable fact is that many cases faced by Muslims need answers from authorized institutions. The existence of official institutions such as the MUI, Muslims do not lose direction to ask for a fat wa concerning contemporary Islamic law.

Keywords: Fatwa, Contemporary 
Supardin

\section{A. PENDAHULUAN}

Negara Indonesia merupakan bangsa yang berpenduduk mayoritas beragama Islam, sehingga dalam kancah politik di Indonesia cukup mewarnai dalam kehidupan berbangsa dan bernegara. Demikian halnya mengenai lembaga-lembaga fatwa tumbuh dan berkembang yang didominasi oleh lembaga fatwa Majelis Ulama Indonesia (MUI).

Mejelis Ulama Indonesia merupakan salah satu lembaga fatwa yang diakui keberadaannya karena MUI memiliki sumber daya manusia intelek yang terdiri atas berbagai disiplin ilmu, baik ilmu-ilmu Keislaman maupun ilmu-ilmu umum, seperti ilmu kedokteran. Ilmu kedokteran digunakan dalam meneliti dan menentukan kadar makanan yang mengandung alkohol, sehingga dapat difatwakan halal atau haramnya suatu makanan dan atau minuman. Adanya perpaduan ilmu yang dimiliki oleh lembaga MUI, maka makanan atau minuman yang dikonsumsi oleh masyarakat umum dapat diberikal label halal, sehingga masyarakat tidak ragu-ragu untuk mengkonsumsinya.

Lembaga-lembaga fatwa di Indonesia cukup banyak, selain lembaga MUI, juga dari lembaga-lembaga keagamaan seperti NU, Muhammadiyah dan sebagainya. Kesemuanya mempunyai pengaruh terhadap masyarakat muslim di Indonesia, sehingga terkadang berbeda pendapat dalam memutuskan dan menetapkan fatwanya, misalnya dalam penentuan hari lebaran dan masalah-masalah hukum Islam kontemporer. Masalah hukum kontemporer yang dimaksud adalah kejadian-kejadian yang muncul dalam masyarakat yang tidak pernah terjadi pada masa Nabi Muhammad saw. seperti bayi tabung. Persoalan seperti ini memerlukan ijtihad, dan ijtihad tidak dapat dipedomani dari hasil personal saja, tetapi sedapat mungkin dihasilkan oleh kesepakatan bersama dalam bentuk ijma'.

Persoalan-persoalan hukum kontemporer, dapat diserap oleh lembaga-lembaga fatwa keagamaan yang kemudian diputuskan oleh lembaga MUI, sehingga dapat berlaku secara nasional. Oleh karena itu, lembaga fatwalah yang dapat menemukan dan menetapkan hukumnya, dan yang paling berkompoten di Indonesia adalah lembaga fatwa MUI. Berdasarkan latar belakang tersebut, maka masalah yang akan diuraikan dalam pembahasan tulisan ini adalah "bagaimana daya serap lembaga-lembaga fatwa di Indonesia terhadap masalah-masalah hukum kontemporer" .

\section{B. PEMBAHASAN}

\section{Pengertian Fatwa dan Hukum Kontemporer}

Secara etimologi, fatwa adalah jawab atau keputusan/pendapat yang diberikan oleh mufti tentang sesuati masalah; biasa juga disebut nasihaSt orang alim atau pelajaran baik/petuah. ${ }^{1}$ Fatwa dalam bahasa Arab juga maknanya sama, فتوى ج فتاوى artinya fatwa, jawab pertanyaan hukum, petua. ${ }^{2}$ Pengertian fatwa dalam internet, fatwa ialah suatu keputusan atau nasihat resmi yang diambil oleh dewan mufti atau ulama.

\footnotetext{
${ }^{1}$ Departemen Pendidikan Nasional. Kamus Besar Bahasa Indonesia, Edisi III (Cet I; Jakarta: Balai Pustaka, 2001), h. 314.

Mufti yang dimaksud adalah pemberi fatwa untuk memutuskan masalah yang berhubungan dengan hukum Islam, lihat Departemen Pendidikan Nasional. Kamus Besar Bahasa Indonesia, Edisi III (Cet I; Jakarta: Balai Pustaka, 2001), h. 758.

${ }^{2}$ Mahmud Yunus, Kamus Arab - Indonesia (Jakarta: PT Hidakarya Agung, 1990 M-1311 H), h. 308.
} 
Menurut M. Quraish Shihab, fatwa adalah petuah, nasihat, atau jawaban pertanyaan hukum dalam ajaran Islam. Fatwa seorang mufti tidak mengikat siapa pun, karena betapapun tinggi dan luas pengetahuan sang mufti, ia tetap manusia biasa yang dapat keliru. ${ }^{3}$ Dalam ensiklopedi hukum Islam, fatwa berarti pendapat yang dikemukakan oleh seorang mujtahid atau fakih sebagai jawababn yang diajukan peminta fatwa dalam suatu kasus yang sifatnya tidak mengikat. ${ }^{4}$ Seorang mufti hampir dapat dikatakan jujur dan objektif, tetapi sebagai seorang manusia biasa dapat saja keliru karena kecenderungan subjektifitas dan keterbatasan ilmu yang dimiliki.

Fatwa yang dikeluarkan oleh MUI sebagai suatu keputusan tentang masalah ijtihadiyah yang terjadi di Indonesia. Fatwa itu dijadikan sebagai pegangan atau dasar hukum terhadap pelaksanaan ibadah umat Islam di Indonesia. ${ }^{5}$ Dengan demikian lembaga fatwa merupakan suatu tempat perkumpulan ulama dan cendekiawan muslim untuk memutuskan atau memberikan nasihat pada orang-orang muslim terhadap persoalan-persoalan hukum Islam.

Persoalan-persoalan hukum Islam itu bukan hanya masalah ibadah, tetapi juga menyangkut persoalan lain seperti mu'amalah. Suatu kenyataan yang tidak dapat dipungkiri lagi, bahwa banyak kasus yang dihadapi oleh umat Islam yang memerlukan jawaban dari lembaga yang berwewenang. Adanya lembaga resmi seperti MUI, umat Islam tidak kehilangan arah untuk meminta fatwa menyangkut hukum Islam kontemporer.

Kontemporer menurut bahasa berarti pada waktu yang sama, semasa, sewaktu, pada masa kini, dewasa ini. ${ }^{6}$ Masalah hukum kontemporer yang dimaksudkan adalah problem yang dihadapi oleh umat Islam kekinian yang tidak pernah terjadi pada masa Nabi saw. dan dasar hukumnya tidak ditemukan dalam al-Qur'an maupun hadis.

Demikian pula masalah-masalah tersebut tidak terdapat dalam fikih klasik (fikih empat mazhab dan sebagainya), sehingga memerlukan interpretasi yang bermacam-macam. Oleh karena itu, masalah-masalah hukum kontemporer diperlukan berbagai disiplin ilmu para cendekiawan muslim/ulama, sehingga umat Islam dapat menemukan kepastian hukumnya.

\section{Peranan Lembaga Fatwa dalam Menyerap Masalah Hukum Kontemporer}

Indonesia sebagai negara hukum, di dalamnya termuat hukum Islam yang diyakini memiliki keterkaitan dengan sumber dan ajaran Islam. Hukum Islam yang dimaksudkan adalah peraturan-peraturan yang bersumber dari wahyu yang kemudian diformulasikan ke dalam produk pemikiran hukum berupa, fikih, fatwa ulama, undangundang, dan yurisprudensi (keputusan pengadilan). Salah satu produk pemikiran hukum Islam adalah fatwa, dan fatwa yang dimaksudkan adalah fatwa ulama, kemudian fatwa ulama yang dimaksud adalah fatwa lembaga Majelis Ulama Indonesia (MUI).

Lembaga MUI dalam melakukan fatwanya sangat terbatas terutama pada rezim orde baru (1967-1982) senantiasa muncul kecurigaan-kecurigaan terhadap gerakangerakan umat Islam. Politik hukum cenderung sangat birokratis dan otoriter serta

${ }^{3}$ M. Quraish Shihab, Fatwa-fatwa M. Quraish Shihab (Cet. II; Bandung: Mizan, 2001), h. ix.

${ }^{4}$ Abdul Azis Dahlan et al., Ensiklopedi Hukum Islam, Jilid I (Cet. V; Jakarta: Ichtiar Baru van Hoeve, 2001), h. 326.

${ }^{5}$ http://id.wikipedia.org/wiki/fatwa.

${ }^{6}$ Departemen Pendidikan Nasional. Kamus Besar Bahasa Indonesia, h. 591. 
Supardin

bersifat konservatif/ortodoks atau elitis, meskipun tahun 1970-an lahir berbagai produk hukum Islam, termasuk undang-undang perkawinan dan lahirnya lembaga MUI. Lembaga MUI berdiri pada tanggal 26 Juli 1975 M/7 Rajab 1395 H di Jakarta, ${ }^{7}$ tetapi kinerja MUI dalam memberikan fatwa sangatlah terbatas, karena bangsa Indonesia disibukkan dengan berbagai gangguan dan ancaman, baik dari dalam maupun dari luar negara Indonesia.

Pada tahun (1982-1985) merupakan periode kritis pemerintah orde baru dengan umat Islam, karena disibukkan oleh diskusi dan seminar tentang asas tunggal Pancasila, sehingga lembaga-lembaga Keislaman seperti MUI dan Peradilan Agama diabaikan. Ketika terjadi sikap akomodatif pemerintah (1985-1998) terjadilah saling pengertian antara pemerintah orde baru dan umat Islam. ${ }^{8}$ Pada periode ini lahirlah produk hukum Islam seperti undang-undang Peradilan Agama dan Kompilasi Hukum Islam. Undang-undang dan KHI ini lahir dari konfigurasi politik yang demokratis dan karakter hukum yang responsif, sehingga mencerminkan harapan baru bagi umat Islam terhadap pencapaian dan pencerminan rasa keadilan.

Pada orde baru ini, dikenal pula dengan penggantian pucuk pimpinan negara, dari Presiden Soekarno (selama 21 tahun dari tahun 1945-1966) ke Presiden Soeharto (selama 32 tahun dari tahun 1966-1998), resminya pada bulan Maret 1968. Orde lama tumbang kemudian muncul orde baru. Orde baru ini dalam proses sosialisasi hukum Islam mulai nampak dengan hadirnya berbagai perundang-undangan, dan pelaksanaan kegiatan keagamaan. Misalnya pelaksanaan MTQ pertama tingkat nasional tahun 1969 di Makassar. Selain itu, organisasi sosial Keislaman termasuk partai umat Islam semakin tumbuh dan berkembang seperti Muhammadiyah, Nahdatul Ulama, Majelis Ulama Indonesia (MUI), Pesantren, Ikatan Cendekiawan Muslim Indonesia (ICMI), Dewan Dakwah Islamiyah Indonesia (DDII) Gabungan Usaha Perbaikan Pendidikan Islam (GUPPI), Majelis Dakwah Islamiyah (MDI), Pendidikan Tinggi Dakwah Islam (PTDI), Komite Indonesia untuk Solidaritas Dunia Islam (KISDI), Masyumi, Partai Persatuan Pembangunan (PPP). Demikian pula organisasi kemahasiswaan Islam tumbuh dan berkembang dalam dunia kampus seperti Himpunan Mahasiswa Islam (HMI), Muslimin Indonesia (MI) atau Parmusi, Pergerakan Mahasiswa Islam Indonesia (PMII), Ikatan Mahasiswa Muhammadiyah (IMM), dan lain-lain. Konfigurasi politik termasuk hukum Islam mengalami pergolakan dalam percaturan perikehidupan bangsa.

Pergolakan pilitik dan hukum pada orde baru, dibagi kepada dua bagian besar, yaitu: Pertama, periode 1965-1970 merupakan periode transisi dalam sistem politik di Indonesia, dari masa orde lama ke masa orde baru. Kedua, periode 1971-1998 merupakan periode membangun basis kekuatan bagi pendukung orde baru, sebagai sebuah institusi baru dalam sistem politik. Konfigurasi politik orde baru ini merupakan satu kesatuan yang utuh. Oleh karena itu pada kedua periode ini kegiatan-kegiatan keagamaan dilakukan atas dasar atauran perundang-undangan yang berlaku termasuk lembaga MUI.

Kegiatan-kegiatan keagamaan masih juga terbatas, karena pemerintah masih mencari pola yang cocok untuk kondisi masyarakat Indonesia yang heterogen. Hal yang menyulitkan bagi pemerintah orde baru adalah usaha kodifikasi dan unifikasi

${ }^{7}$ http://id.wikipedia.org/wiki/fatwa.

${ }^{8} \mathrm{http} / / /$ id.wikipedia.org/wiki/fatwa. 
bidang hukum tertentu, termasuk kesulitan dalam memberikan fatwa MUI. Kesulitan ini disebabkan adanya semangat dan kemajemukan tatanan hukum yang hidup dan berkembang dalam masyarakat yang meliputi hukum Barat, hukum adat, dan hukum Islam. ${ }^{9}$ Ketiga hukum tersebut merupakan sumber produk hukum nasional, dalam hukum Islam salah satu formulasinya adalah bentuk fatwa ulama.

Pada era reformasi, dikenal sebagai masa kebebasan dalam mengeluarkan pikiran dan pendapat. Demonstrasi terjadi dan bergulir di berbagai penjuru kota di Indonesia. Dalam era ini tumbanglah orde baru tahun 1998, lahirlah partai-partai umat Islam untuk dijadikan sebagai wadah aspirasi umat Islam, baik dari golongan NU, Muhammadiyah, maupun ormas Islam lainnya. Semakin nampaklah para pengikut ormas Islamnya, fatwa MUI hampir diabaikan, karena MUI dianggap ulama pemerintah.

Dalam era reformasi, pemerintahan telah dilaksanakan oleh empat orang presiden, masing-masing Presiden B.J. Habibie dengan nuansa keilmuan dan Keislaman (seorang tokoh cendekiawan muslim). Presiden Abdurrahman Wahid alias Gus Dur dengan nuansa keulamaan dan kekiyaian (ulama pembaru). Presiden Megawati Soekarnoputri yang akrab dipanggil Mbak Mega dengan nuansa nasionalisme yang tinggi yang diwariskan oleh ayahandanya yakni Presiden Soekaro (wanita pemberani dan bernuansa gender) . Kini Republik Indonesia di bawah kendali Presiden Susilo Bambang Yudhoyono dengan sapaan SBY Sang Demokrat yang didampingi oleh Wakil Presiden Muhammad Yusuf Kalla dengan sapaan Bang Ucu Sang Pengusaha Sukses. Negara Indonesia telah dipimpin oleh enam orang presiden, kesemuanya adalah beragama Islam. Tetapi juga belum melahirkan syari'at Islam secara menyeluruh, kecuali pemerintah memberikan otonomi khusus, yaitu pelaksanaan syari'at Islam di Provinsi Nanggroe Aceh Darussalam yang telah dilanda peperangan/perang saudara. Kini provinsi tersebut telah damai, namun di balik itu fatwa pun tidak menyentuh hati masyarakatnya untuk senantiasa hidup damai dan saling menolong dalam hidup kegotongroyongan.

Lembaga fatwa di Indonesia yang banyak mempengaruhi masyarakat muslim adalah Nahdatul Ulama dengan fatwanya Bahsul al-Masāil, Muhammadiyah dengan fatwanya Majelis Tarjih, dan MUI dengan lembaga fatwanya. Ketiga lembaga fatwa tersebut kecenderungannya mengikuti mazhab Imam Syafi'i.

Nahdatul Ulama dalam mengikuti suatu pendapat, maka NU pada muktamar pertama di Surabaya telah menetapkan peringkat kualitas pendapat yang dipedomani dalam memilih pendapat, yakni:

1. Pendapat yang disepakati oleh asy-Syaikhan (al-Nawawi dan al-Rafi'i).

2. Pendapat yang dipegangi oleh al-Nawawi saja.

3. Pendapat yang dipegangi oleh al-Rafi'i saja.

4. Pendapat yang didukung oleh mayoritas ulama.

5. Pendapat ulama yang terpandai.

${ }^{9}$ M. Yahya Harahap, Kedudukan, Kewenangan, dan Acara Peradilan Agama: Undang-Undang Nomor 7 Tahun 1989 (Jakarta: Pustaka Kartini, 1993), h. 17. 
Supardin

6. Pendapat ulama yang paling wara. ${ }^{10}$

Nahdatul Ulama (NU) dalam rumusan pengambilan keputusannya dikenal dengan istilah istinbat jama' $i$ (penggalian hukum-hukum Islam secara kolektif.

Lembaga fatwa Muhammadiyah dalam organisasinya, kemaslahatan umat merupakan sesuatu yang harus diwujudkan. Sebab dalam persoalan-persoalan yang berkenaan dengan mu'amalah, peranan akal cukup banyak untuk mewujudkan kemaslahatan umat. ${ }^{11}$ Kemaslahatan umat merupakan jiwa dari aspek hukumnya terutama yang berhubungan dengan aspek mu'amalah. Kemaslahatan dalam bidang mu'amalah harus didahulukan daripada Nash, apabila bertentangan antara satu dengan lainnya. Maksud dari hal tersebut adalah maslahat dalam bidang mu'amalah dapat men-takhsis nash, tetapi tidak bermaksud membatalkan nash. ${ }^{12}$ Menyangkut maslahat, lebih diutamakan pada kepentingan umum daripada kepentingan perorangan.

Sebuah kasus yang terjadi kepada para kaum ibu, yakni masalah alat kontrasepsi menimbulkan perdebatan dan pertentangan yang cukup memukau masyarakat muslim. Alat IUD (Intra Uterine Device) ${ }^{13}$ yaitu Alat Kontrasepsi dalam Rahim (AkdR) yang dipasang pada dinding rahim wanita untuk menghalangi pertemuan sperma dan ovum. Menurut Majelis Tarjih Muhammadiyah dalam fatwanya bahwa alat tersebut diperbolehkan, tetapi pemasangan alat tersebut dilakukan oleh juru rawat atau dokter wanita. ${ }^{14}$ Alasan yang sangat mendasar adalah jika laki-laki yang melakukannya secara otomatis ia melihat langsung aurat wanita tersebut, apalagi yang disaksikan adalah alat kelamin yang merupakan harta yang paling dirahasiakan.

Daya serap lembaga fatwa di Indonesia bersifat tidak mengikat, tidak punya sanksi duniawi melainkan sanksi moril atau sanksi ukhrawi. Lembaga-lembaga fatwa di Indonesia pada sasarnya merujuk dari ijtihad kolektif. Menurut Harun Nasution, ijtihad kolektif sangat dibutuhkan tetapi hanya bersifat pada skala nasional bukan skala internasional. Alasan yang dikemukakannya adalah disebabkan permasalahan keagamaan yang muncul di zaman modern ini tidak sama, pengaruh sains dan teknologi pun berbeda. Selain itu, adanya keberagaman penafsiran bidang keagamaan dan pengamalan agama pada tiap-tiap negara muslim. ${ }^{15}$ Adanya keberagaman pemahaman keagamaa tersebut dapat menimbulkan inspirasi baru bagi para cendekiawan muslim dan kaum ulama untuk terus menggali hukum Islam yang serba komprehensif.

Daya serap lembaga fatwa yang dikeluarkan oleh Majelis Ulama Indonesia, mempunyai tujuan dan kemaslahatan umat, yang tentunya diperlukan analisis yang

7.

${ }^{10}$ Pengurus Besar Nahdatul Ulama, Ahkamul Fuqaha, Juz I (Semarang: CV Toha Putra, t.th.), h.

${ }^{11}$ Arifin M.T., Muhammadiyah Potret yang Berubah (Cet. I; Surakarta: IGPFB, 1990), h. 23.

${ }^{12}$ Amir Maksum, Pemahaman Tajdid dalam Muhammdiyah (Yogyakarta: Bina Utama, 2002), h. 82. Lihat pula Mustafa Zaid, al-Maslahat fi al-Tasyri' al-Islami wa Najmu al- Din al- Tufi (t.tp.: Dar alFikr, 1964), h. 121.

${ }^{13}$ Mathrew W. Garrey, Obstetric Illustred (London: Churchill Livingstone, 1989), h. 519.

${ }^{14}$ Pimpinan Pusat Majelis Tarjih Muhammadiyah, Membina Keluarga Sejahtera (Yogyakarta: Persatuan, t.th.), h. 50.

${ }^{15}$ Harun Nasution, "Ijtihad Sumber Ketiga Ajaran Islam" dalam Jalaluddin Rahmat, Ijtihad dalam Sorotan (Bandung: Mizan, 1991), h. 115. 
mendalam. Untuk memecahkan persoalan yang dihadapi, diperlukan disiplin ilmu interdispliner.

Bentuk daya serap fatwa yang digunakan oleh Majelis Ulama Indonesia ialah seperti pada kasus perkawinan beda agama, yakni: Seorang laki-laki muslim dilarang mengawini wanita bukan muslim. Tentang perkawinan antara laki-laki muslim dengan wanita ahli kitab terdapat perbedaan pendapat. Akan tetapi setelah mempertimbangkan mafsadahnya lebih besar dari maslahatnya, maka MUI memfatwakan perkawinan tersebut hukumnya haram. ${ }^{16}$ Fatwa pengharaman ini merupakan suatu pembaruan hukum Islam dengan pertimbangan, bukan saja dilihat dari segi muamalah tetapi juga dari aspek ikidah dan ibadah lainnya. Sebab kalau dalam rumah tangga terjadi dualisme agama maka keharmonisan dalam menjalankan ibadah tidak dapat dilaksanakan dengan maksimal. Misalnya yang satu membolehkan untuk melaksanakan sesuatu pekerjaan sedangkan yang lain melarang bahkan mengharamkan.

Kalau terjadi dualisme keinginan yang sifatnya mendasar, maka tujuan dari perkawinan itu tidak dapat tercapai. Sedangkan tujuan pokok dari perkawinan dalam sebuah rumah tangga adalah menciptakan keluarga yang harmonis, tenteram lahir dan batin. Ketenangan dapat diperoleh jika persamaan emosional secara mendasar adalah sama dalam hal ini satu agama, artinya sedangkan satu keyakinan dalam rumah tangga belum tentu melaksanakan ibadah dengan baik, apalagi kalau berbeda keyakinan.

Selain menyangkut keyakinan, juga diatur secara jelas mengenai keturunan yang sah berdasarkan hukum Islam. Majelis Ulama Indonesia juga telah menyepakati hasil kemajuan teknologi tentang bayi tabung yang tidak diatur dalam nash maupun fikih klasik, bahwa hukum dari inseminasi buatan/bayi tabung ada yang boleh/halal dan ada yang diharamkan.

Fatwa tentang inseminasi buatan/bayi tabung hukumnya boleh atau halal apabila sperma dan ovum yang diambil dari pasangan suami istri yang sah. Inseminasi buatan/bayi tabung hukumnya haram bila sperma dan ovum diambil dari pasangan suami istri untuk istrinya yang lain, apalagi kalau bukan pasangan suami isteri. ${ }^{17}$ Dari keputusan fatwa MUI tersebut memberi peluang bagi pasangan suami istri yang sah untuk mendapatkan keturunan dengan jalan bayi tabung dari sperma kedua pasangan suami istri yang sah itu. Adanya kebolehan bayi tabung itu karena hasil dari kemajuan teknologi dan tidak ditemukan dalam fikih klasik maupun dalam al-Qur'an dan hadis, dengan syarat dari, oleh, dan untuk kedua pasangan suami istri yang sah berdasarkan hukum Islam. Keputusan fatwa MUI ini merupakan hasil dari metode pembaruan hukum Islam yang bersumber dari kesepakatan bersama yang disebut dengan metode kolektif. Fatwa dalam pembaruan hukum Islam bila ditinjau dari pendekatan yurudis formal, dapat ditemukan pada Instruksi Presiden Nomor 1 tahun 1991 tentang Kompilasi Hukum Islam. ${ }^{18}$

\footnotetext{
${ }^{16}$ Majelis Ulama Indonesia, Keputusan Musyawarah Nasional II MUI-Majalah Mimbar Ulama Nomor 171 tahun XVI April 1992 (Jakarta: Sekretariat MUI, 1992), h. 66.

${ }^{17}$ Surat Keputusan MUI Nomor Kep.925/XI/1990, tanggal 26 November 1990, tentang Inseminasi Buatan.

${ }^{18}$ Lihat Republik Indonesia, Inpres Nomor 1 tahun 1991 tentang Kompilasi Hukum Islam. Dituangkan pula dalam Kepmen Agama Nomor 154 tahun 1991 tentang Pelaksanaan Inpres Nomor 1 tahun 1991 tanggal 10 Juni 1991. Presiden menginstruksikan kepada Menteri Agama untuk
} 
Supardin

Kompilasi inilah yang merupakan metode pembaruan hukum Islam kontemporer berdasarkan materi hukum Islam di Indonesia. Lahirnya KHI di Indonesia karena persoalan yang dihadapi umat Islam semakin kompleks dan belum memperlihatkan hukum Islam sebagai suatu hukum yang dipedomani dalam berbangsa dan bernegara.

Persoalan dikatakan kompleks, karena berlakunya hukum Islam di Indonesia tergantung pada umat Islam sebagai umat mayoritas yang merupakan faktor pendukung utama. Hukum Islam telah dilaksanakan di Indonesia selama kurun waktu lama, namun belum memperlihatkan dirinya sebagai hukum yang utuh berdasarkan konsep dasar al-Qur'an dan hadis. Kenyataan tersebut merupakan sebuah refleksi berlangsungnya proses Islamisasi secara berkesinambungan, yang berpacu dengan kemajuan dan perkembangan zaman. ${ }^{19}$ Salah satu bentuk jawaban dari permasalahan hukum kontemporer itu adalah adanya fatwa khususnya lembaga fatwa MUI.

Melihat proses Islamisasi perkembangan dan pembaruan hukum Islam di Indonesia, dapat dilihat beberapa contoh pada KHI yang mengalami pembaruan, antara lain: menyangkut harta gono-gini atau harta bersama suami istri (dalam fikih klasik tidak ditemukan); bagian ayah dan ibu sama-sama bagiannya (masing-masing 1/3 dan atau $1 / 6$, sedangkan dalam al-Qur'an bagian ayah $1 / 6$ atau mendapat sisa); ahli waris pengganti (dalam fikih klasik tidak ditemukan ahli waris pengganti melainkan kasus munasakhah); dan sebagainya.

Kalau tidak menggunakan bentuk pendekatan dari formulasi yang sama dalam proses pemberlakuan hukum Islam di Indonesia seperti fatwa, maka akan mengakibatkan kerancuan dan ketidakberaturan materi hukum yang diberlakukan. Dengan demikian, masyarakat dengan mudah dipermainkan oleh penguasa dan atau oleh penegak hukum yang kurang memahami tujuan syariat itu sendiri. Akan tetapi kalau dasar hukum dan metode yang digunakan dalam pembaruan hukum itu, hasilnya pun akan meminimalisasi kerancuan dan kecurangan dalam pemberlakuan materi hukum itu. Sebab tujuan utama dalam menerapkan hukum adalah untuk melahirkan masyarakat yang hidup teratur dan tenteram yang tujuan akhirnya hidup bahagia di dunia dan akhirat.

Masyarakat yang taat pada fatwa ulama, berarti ia telah menaati syariatnya, sebab hasil fatwa ulama merupakan bentuk ijtihad ulama secara kolektif, dan ijtihad itu sendiri merupakan sumber dalam menetapkan hukum . Lembaga fatwa yang sangat kolektif adalah fatwa Majelis Ulama Indonesia. Oleh karena itu lembaga fatwa MUI merupakan tempat perhimpunan para kaum cendekiawan muslim dan ulama dengan tujuan membahas masalah-masalah hukum kontemporer yang kemudian menemukan dan memutuskan hukumnya.

melaksanakan dan menyebarluaskan inpres tersebut, dan Menteri Agama mengeluarkan keputusan kepada instansi Departemen Agama dan pemerintah lainnya untuk menyebarluaskan inpres tersebut.

${ }^{19}$ H. Abdurrahman, Kompilasi Hukum Islam di Indonesia (Cet. III; Jakarta: CV Akademika Pressindo, 2001), h. 2. 


\section{PENUTUP}

\section{Kesimpulan}

Berdasarkan uraian tersebut di atas, maka dapat disimpulkan bahwa kedudukan lembaga fatwa merupakan bentuk formulasi hukum Islam yang bersumber dari wahyu untuk memberikan jawaban terhadap masyarakat muslim yang sedang menghadapi masalah-masalah hukum kontemporer, khususnya dalam hukum keluarga.

Lembaga-lembaga fatwa di Indonesia mempunyai bentuk dan sifat tidak mengikat, artinya fatwa tersebut tidak mempunyai sanksi duniawi, tetapi mempunyai sanksi moril. Daya serap fatwa di Indonesia telah banyak mengeluarkan keputusan, dalam organisasi keagamaan maupun dalam skala nasional yakni Majelis Ulama Indonesia (MUI).

\section{Implikasi}

Lembaga fatwa di Indonesia sebaiknya dihimpun dalam satu wadah yang kemudian disampaikan kepada umat secara nasional, sehingga tidak terjadi dualisme penafsiran dalam mejalankan perikehidupan keagamaan. Oleh karena itu, lembaga fatwa yang sepatutnya untuk menyampaikan kepada masyarakat secara nasional adalah MUI. Akhirnya saran dan kritik dibutuhkan, mudah-mudahan tulisan ini bermanfaat, dan semoga Allah meridainya.

\section{DAFTAR PUSTAKA}

Al-Qur'an.

Abdurrahman, H. Kompilasi Hukum Islam di Indonesia. Cet. III; Jakarta: CV Akademika Pressindo, 2001.

Dahlan, Abdul Azis et al. Ensiklopedi Hukum Islam. Jilid I. Cet. V; Jakarta: Ichtiar Baru van Hoeve, 2001.

Departemen Agama. Kepmen Agama Nomor 154 tahun 1991 tentang Pelaksanaan Inpres Nomor 1 tahun 1991 tanggal 10 Juni 1991.

Departemen Pendidikan Nasional. Kamus Besar Bahasa Indonesia. Edisi III. Cet I; Jakarta: Balai Pustaka, 2001.

Garrey, Mathrew W. Obstetric Illustred (London: Churchill Livingstone, 1989.

Harahap, M. Yahya. Kedudukan, Kewenangan, dan Acara Peradilan Agama: UndangUndang Nomor 7 Tahun 1989. Jakarta: Pustaka Kartini, 1993.

Internet. http://id.wikipedia.org/wiki/fatwa.

Majelis Ulama Indonesia. Keputusan Musyawarah Nasional II MUI-Majalah Mimbar Ulama Nomor 171 tahun XVI April 1992. Jakarta: Sekretariat MUI, 1992.

Maksum, Amir. Pemahaman Tajdid dalam Muhammdiyah. Yogyakarta: Bina Utama, 2002.

M.T., Arifin. Muhammadiyah Potret yang Berubah. Cet. I; Surakarta: IGPFB, 1990.

Nasution, Harun. "Ijtihad Sumber Ketiga Ajaran Islam" dalam Jalaluddin Rahmat, Ijtihad dalam Sorotan. Bandung: Mizan 1991.

Pengurus Besar Nahdatul Ulama. Ahkamul Fuqaha. Juz I. Semarang: CV Toha Putra, t.th. 
Kedudukan Lembaga Fatwa dalam Fikih Kontemporer

Supardin

Pimpinan Pusat Majelis Tarjih Muhammadiyah. Membina Keluarga Sejahtera. Yogyakarta: Persatuan, t.th.

Republik Indonesia. Inpres Nomor 1 tahun 1991 tentang Kompilasi Hukum Islam.

Shihab, M. Quraish. Fatwa-fatwa M. Quraish Shihab. Cet. II; Bandung: Mizan, 2001.

Surat Keputusan MUI Nomor Kep.925/XI/1990, tanggal 26 November 1990, tentang Inseminasi Buatan.

Yunus, Mahmud. Kamus Arab - Indonesia.Jakarta: PT Hidakarya Agung, 1990.

Zaid, Musafa. Al-Maslahat fī al-Tasyri' al-Islami wa Najmu al-Dïn al- Tufi. t.tp.: Dar al-Fikr, 1964. 